\title{
TANGGUNG JAWAB RUMAH SAKIT TERHADAP PASIEN DALAM PELAKSANAAN PELAYANAN KESEHATAN
}

\author{
Ampera Ampera \\ Mahasiswa Program Pascasarjana Universitas Muslim Indonesia \\ email : Ampera.umi@ymail.com
}

\begin{abstract}
The responsibilities of the hospital for the exercise of the rights of the patient include: The right to medical information, the right to the consent of medical action, the right to choose a doctor and the right to the contents of the medical record has not gone well in accordance with the prevailing laws and regulations.
\end{abstract}

Keywords : Hospital; Patient Responsibility;

\begin{abstract}
Abstrak
Tanggung jawab rumah sakit untuk melaksanakan hak-hak pasien meliputi: Hak atas informasi medis, hak atas persetujuan tindakan medis, hak untuk memilih dokter dan hak atas isi catatan medis belum hilang. sesuai dengan hukum dan peraturan yang berlaku.
\end{abstract}

Kata kunci: Rumah Sakit; Tanggung Jawab pasien;

\section{A. PENDAHULUAN}

Pelaksanaan tanggung jawab rumah sakit terhadap pasien dalam pelayanan kesehatan merupakan sebuah kewajiban yang harus dipenuhi agar setiap tindakan, pengobatan dan perawatan yang diterima oleh pasien menjadi lebih bermutu dan berhasil guna untuk menyembuhkan dan menyelamatkan nyawa pasien.Keselamatan pasien adalah hal sangat utama dalam setiap pemberian pelayanan kesehatan yang dilakukan oleh dokter kepada pasien (aegroti salus lex suprema).

Rumah sakit dalam memberikan pelayanan kesehatan kepada pasien sangat dipengaruhi oleh tiga komponen yaitu : kualitas pelayanan yang diberikan, siapa yang memberikan pelayanan dan konsumen (pasien) yang menerima dan menilai pelayanan yang diterimanya. ${ }^{1}$ Jika Rumah sakit mampu menyelenggarakan pelayanan kesehatan yang berkualitas yang diberikan oleh tenaga-tenaga kesehatan yang profesional yang bekerja sesuai dengan standar-standar pelayanan rumah sakit dan pasien sebagai penerima manfaat pelayanan kesehatan merasa puas sesuai dengan keinginan dan harapannya, maka dapat dikatakan bahwa pelayanan kesehatan tersebut telah bermutu. Dalam Pasal 29 ayat (1) huruf b. Undang-Undang Nomor 44 Tahun 2009 Tentang Rumah Sakit yang berbunyi : "Setiap rumah sakit berkewajiban memberi pelayanan kesehatan yang aman,bermutu, antidiskriminasi, dan efektif dengan mengutamakan kepentingan pasien sesuai dengan

\footnotetext{
${ }^{1}$ Triwundari Tutik, Titik, Perlindungan Hukum Bagi Pasien, Prestasi Pustaka,.Jakarta, 2010.
} 
standar pelayanan Rumah Sakit.

Pelaksanaan tanggung jawab rumah sakit dalam memberikan pelayanan kesehatan yang bermutu kepada pasien tercermin dalam pelaksanaan kewajiban rumah sakit untuk memenuhi hak-hak pasien yang dilakukan oleh dokter,perawat,bidan dan tenaga kesehatan lainnya berdasarkan kewenangan dan kompetensinya yang sesuai dengan standar profesi,standar operasional prosedur dan standar pelayanan medik yang berlaku di rumah sakit tersebut.

Hubungan hukum antara dokter atau pihak rumah sakit dengan pasien dalam pelayanan kesehatan menempatkan dokter atau pihak rumah sakit sebagai subjek hukum yang berkewajiban memberikan upaya pelayanan kesehatan secara maksimal berdasarkan segala kemampuan dan keahlian yang dimilikinya untuk melakukan penyembuhan dan atau pemulihan kesehatan pasien sebagai hak pasien dan sebaliknya pasien sebagai subjek hukum berkewajiban untuk membayar biaya penyembuhan dan pemulihan kesehatannya yang merupakan hak dokter atau pihak rumah sakit.

Penyebab utama dari gugatan atau tuntutan hukum atas pertanggung jawaban dokter atau pihak rumah sakit dalam pelayanan kesehatan kepada pasien bermula dari ketidak puasan pasien atas mutu pelayanan yang diberikan oleh rumah sakit.Rumah sakit dianggap gagal memenuhi harapan pasien untuk mendapatkan penyembuhan dan pemulihan kesehatannya, padahal mereka telah memenuhi seluruh kewajibannya termasuk membayar biaya penyembuhan dan pemulihan kesehatan mereka selama meraka berobat dan atau dirawat di rumah sakit tersebut.

Sebagai realitas yang terjadi di masyarakat, beberapa kasus gugatan atau tuntutan hukum atas pertanggung jawaban rumah sakit dalam memberikan pelayanan kesehatan kepada pasien yang telah sampai ke tahap penuntutan, baik melalui pengadilan maupun Majelis Disiplin Tenaga Kesehatan Indonesia (MDTKI) antara lain sebagai berikut:

1. Kasus Rumah Sakit OmniHospital International di Tangerang tahun 2009.

2. Kasus Rumah Sakit Wahidin Sudirohusodo di Makassar tahun 2010.

Berdasarkan beberapa kasus yang terjadi,ternyata bahwa gugatan atau tuntutan pasien terhadap dugaan malpraktek yang dilakukan oleh dokter atau pihak rumah sakit dalam pelayanan kesehatan bersumber dari kesalahan atau kelalaian dokter yang bekerja tidak sesuai dengan standar operasional prosedur, tidak berdasarkan indikasi medis yang jelas dan tidak memberikan informed consent yang baik dan jelas kepada pasien, sehingga menimbulkan ketidak puasan yang berujung pada gugatan atau tuntutan malpraktek.

Selanjutnya mengenai kelalaian dokter atau pihak rumah sakit dalam memberikan pelayanan kesehatan kepada pasien terutama disebabkan karena dokter atau pihak rumah sakit bekerja tidak cermat, tidak teliti dan tidak hati-hati dalam melakukan sebuah tindakan yang seharusnya dilakukan atau tidak dilakukan berdasarkan kemampuan dan keahliannya sesuai dengan standar operasional prosedur.Pelaksanaan tindakan tersebut, yang menyebabkan terjadinya kerugian pada pasien berupa cacat atau kematian disebut sebagai perbuatan malpraktek kedokteran atau malpraktek medis.

\section{B. ANALISIS DAN PEMBAHASAN}

Kajian mengenai tanggung jawab rumah sakit terhadap pelaksanaan hak-hak pasien dalam pelayanan kesehatan di rumah sakit difokuskan pada pelaksanaan hak pasien atas informasi medis, hak pasien atas persetujuan tindakan medis (informed consent), hak 
untuk memilih dokter dan hak atas rekam medik (medical record).

\section{Tanggung Jawab Rumah Sakit terhadap Pelaksanaan Hak Informasi Medis bagi Pasien}

Pelaksanaan tanggung jawab dokter atau pihak rumah sakit dalam memberikan informasi medis yang jelas dan akurat kepada pasien merupakan sebuah kewajiban sebagaimana diatur dalam Pasal 29 ayat (1) butir a Undang-Undang Nomor 44 Tahun 2009 Tentang Rumah Sakit yang berbunyi "Setiap rumah sakit mempunyai kewajiban memberikan informasi yang benar tentang pelayanan rumah sakit kepada masyarakat".

Kemudian dalam Pasal 45 ayat (3) Undang-Undang Nomor 29 Tahun 2004 Tentang Praktek Kedokteran dijelaskan bahwa setiap dokter dalam menjalankan praktek kedokterannya wajib memberikan penjelasan tentang diagnosis dan tata tata cara tindakan medis; tujuan tindakan medis yang dilakukan; alternatif tindakan lain dan risikonya; risiko dan komplikasi yang mungkin terjadi; dan prognosis terhadap tindakan yang dilakukan.

Selanjutnya kewajiban dokter dalam memberikan informasi yang baik dan benar juga diatur dalam pelaksanaan Kode Etik Kedokteran Indonesia Tahun 2012, mengenai kewajiban dokter menghargai hak-hak pasien bahwa "Seorang dokter wajibmemberikan informasi yang jelas dan memadai sertamenghormatipendapat atautanggapan pasien atas penjelasan dokter ". Selain itu, ditentukan pula bahwa "Seorang dokter seharusnya tidak menyembunyikan informasi yang dibutuhkan pasien, kecuali dokter berpendapat hal tersebut untuk kepentingan pasien, dalam hal ini dokter dapat menyampaikan informasi ini kepada pihak keluarga atau wali pasien“

Selanjutnya dalam Kode etik Rumah Sakit (Kodersi) diatur kewajiban rumah sakit untuk memberikan informasi kepada pasien terkait dengan penyakitnya tertuang sebagaimana dalam Pasal 10 Kode Etik Rumah sakit yang berbunyi : " Rumah sakit harus memberikan penjelasan apa yang diderita pasien, dan tindakan apa yang hendak dilakukan.

Salah satu contoh kasus permasalahan hukum yang terkait dengan pemberian informasi medis adalah kasus hukum Prita Mulyasari versus Rumah Sakit Omni Hospital, yang bermula dari rasa ketidak puasan atas informasi medis yang diberikan oleh pihak Rumah Sakit Omni Hospital Internasional sehingga ia mengirimkan suratsurat elektronik (e-mail) kepada rekan-rekan, dan sahabatnya tentang rasa ketidak puasannya tersebut, yang pada gilirannya Prita Mulyasari harus mendekam di balik jeruji besi dengan tuduhan telah melakukan perbuatan pidana pencemaran nama baik atas nama Rumah Sakit Omni International Hospital tempat Prita Mulyasari mendapatkan perawatan.

Dalam kasus ini, Prita menuntut haknya untuk mendapatkan informasi dan kejelasan dari pihak rumah sakit dan dokter tentang beberapa hal :

1. Hasil laboratorium yang merupakan indikasi dia dirawat inap di rumah sakit

2. Kejelasan mengenai penyakit yang dideritanya.

3. Informasi tentang obat-obat dan tindakan medis yang diberikan.

4. Tujuan pemberian obat-obatan dan tindakan medis yang diterimanya.

Vol. 20 No. 2 November 2018 
Jika mengacu pada tanggung jawab rumah sakit untuk melaksanakan kewajibannya memberikan informasi medis yang jelas dan akurat, maka tidak ada alasan bagi dokter dan pihak rumah sakit untuk tidak memberikan informasi yang jujur dan benar tentang diagnosa penyakit yang menjadi alasan mengapa Prita Mulyasari harus diopname, obat dan jenis tindakan yang akan diberikan kepada Prita Mulyasari selama dalam perawatan.

Mengenai kesalahan pembacaan Hasil laboratorium yang pada pemeriksaan awal, seharusnya dapat dikomunikasikan dengan baik oleh pihak dokter dan rumah sakit.Jika memang ada kesalahan pembacaan hasil pemeriksaan awal maka dokter dan pihak rumah sakit harus mengakuinya dan menjelaskan dengan baik kepada pasien dan menghentikan terapi akibat diagnosis dari penyakitnya. Namun yang terjadi adalah seolah-olah dokter dan pihak rumah sakit tidak mau mengakui kesalahan pemeriksaan awal dan meneruskan terapi atas dasar pemeriksaan yang salah tersebut dan tidak menjelaskan dengan gamblang tentang penyakit yang diderita oleh Prita Mulyasari.

Pelaksanaan tanggung jawab rumah sakit terhadap hak atas informasi medis bagi pasien berdasarkan data kuantitatif yang diperoleh melalui responden dokter dan pasien yang dilakukan pada tiga rumah sakit di Kota Makassar yaitu Rumah Sakit Labuang Baji, Bhayangkara dan Pelamonia, serta satu rumah sakit di Kabupaten Tanatoraja yaitu Rumah Sakit Laki padada diperoleh gambaran sebagai berikut :

\section{Tabel 1}

Distribusi tanggapan Responden dokter terhadap pelaksanaan tanggung jawab Rumah Sakit atas hak informasi medis yang jelas bagi pasien

\begin{tabular}{|c|c|c|}
\hline $\begin{array}{c}\text { Hak informasi medis yang jelas bagi } \\
\text { pasien }\end{array}$ & Jumlah & Persentase \\
\hline Terlaksana & 33 & 82,2 \\
Kadang terlaksana & 6 & 14,3 \\
Tidak terlaksana & 1 & 3,5 \\
\hline Jumlah & $\mathbf{4 0}$ & $\mathbf{1 0 0 \%}$ \\
\hline
\end{tabular}

Sumber: Data primer setelah diolah, Tahun 2016.

Berdasarkan tabel di atas, proporsi dokter yang memberikan tanggapan bahwa pelaksanaan tanggung jawab rumah sakit dalam memberikan informasi medis secara baik dan benar kepada pasien telah terlaksana dengan baik $82,2 \%$, yang mengatakan kadang-kadang terlaksana 14,3\% dan sisanya tidak terlaksana 3,5\%. Hal ini berarti bahwa dokter atau pihak rumah sakit sebagian besar menganggap telah melaksanakan tanggung jawabnya untuk memberikan informasi sehubungan dengan pengobatan, tindakan medis dan perawatan kepada pasien selama dalam penanganan pihak rumah sakit. 
Selanjutnya jika dibandingkan dengan proporsi tanggapan responden pasien dalam pelaksanaan tanggung jawab rumah sakit untuk memberikan informasi medis yang baik,jelas dan akurat kepada pasien yang merupakan hak yang harus diterimanya dalam pelayanan kesehatan, dapat dilihat pada table dibawah ini :

Tabel 2

Distribusi tanggapan Responden pasien terhadap Pemenuhan tanggung jawab rumah sakit atas hak informasi medis yang jelas bagi pasien

\begin{tabular}{|l|c|c|}
\hline \multicolumn{1}{|c|}{$\begin{array}{c}\text { Hak informasi medis yang jelas } \\
\text { kepada pasien }\end{array}$} & Jumlah & Persentase \\
\hline Terlaksana & 20 & 16,9 \\
Kadang terlaksana & 4 & 3,7 \\
Tidak terlaksana & 95 & 79,4 \\
\hline Jumlah & 120 & $100 \%$ \\
\hline
\end{tabular}

Sumber: Data primer setelah diolah, Tahun 2016.

Berdasarkan tabel di atas, proporsi tanggapan pasien mengatakan tanggung jawab dokter atau pihak rumah sakit untuk memberikan informasi medis yang jelas dan akurat tidak terlaksana dengan baik sebesar 79,4\%, kemudian terlaksana dengan baik 16,9\% dan yang kadang-kadang terlaksana 3,7\%.Hasil ini membuktikan bahwa masih perlu dibangun komunikasi yang efektif dan efisien antara dokter atau pihak rumah sakit dengan pasien dalam pelayanan kesehatan, agar apa yang disampaikan oleh dokter kepada pasien dapat dengan mudah dicerna dan dimengerti. Penggunaan bahasa-bahasa medis atau istilah-istilah kedokteran sebisanya dikomunikasikan dengan bahasa sederhana, bahkan jika perlu menggunakan bahasa daerah yang mudah dimengerti oleh pasien tersebut.

Pola komunikasi yang cenderung satu arah disertai sikap dokter yang "arogan" dan paternalistik membuat pasien enggan bertanya kepada dokter.Banyak istilah kedokteran yang membuat pasien kebingungan dan tidak tahu harus bertanya dari mana. Celakanya lagi, banyaknya mitos dan kabar burung yang beredar di masyarakat seputar dunia kesehatan membuat pasien dibanjiri dengan informasi yang salah. 2 Beberapa permasalahan komunikasi dalam bidang kedokteran yang kerap kali muncul ke permukaan, lebih disebabkan karena kurang dipahaminya komunikasi oleh kedua belah pihak, baik dokter maupun pasien. Sungguh ironis bahwa di tengah perkembangan teknologi dan kedokteran saat ini bangsa Indonesia sebenarnya masih sangat terbelakang dalam hal kesehatan. Hal ini tercermin dari perilaku pasien yang karena ketidaktahuannya menyerahkan nasib sepenuhnya kepada dokter atau rumah sakit, sehingga seringkali menjadi korban malpraktik, atau malah bersikap tidak

2. Ong LM, De Haes JC, Hoos AM, Lammes FB. Doctor-patient communication: a review of the literature. Social science \& medicine. 1995, hlm. 40.

Vol. 20 No. 2 November 2018 
peduli dan mencari jalan pintas dengan mengobati dirinya.3 Hasil penelitian ini membuktikan bahwa para dokter atau pihak rumah sakit belum sepenuhnya melaksanakan tanggung jawabnya dalam hal pemberian informasi medis yang baik dan benar kepada pasien.

\section{Tanggung Jawab Rumah Sakit atas Hak persetujuan tindakan medik bagi pasien}

Pada umumnya dokter dalam memberikan tindakan medis kepada pasien terlebih dahulu mendapatkan persetujuan tindakan berupa surat pernyataan persetujuan yang telah ditandatangi oleh pasien. Hal ini selain karena bentuk tanggung jawabnya untuk melaksanakan hak pasien atas persetujuan tindakan medis juga, karena adanya kekuatiran akan tuntutan hukum yang mungkin saja terjadi jika tindakan yang mereka lakukan tidak sesuai dengan yang diharapkan.

Meskipun para dokter dapat berlindung dibalik pernyataan persetujuan tindakan medik yang telah ditandatangani pasien dan atau keluarganya tidaklah berarti tindakan medik yang dilakukannya tidak dapat soal secara hukum, karena syarat lahirnya sebuah persetujuan tindakan medik adalah setelah pasien mendapatkan informasi yang lengkap dan jelas, jujur dan benar dari semua hal yang akan dilakukan pada diri pasien yang menyangkut alasan mengapa tindakan medis tesebut harus dilakukan, apakah resiko tindakan tersebut jika dilakukan atau tidak dilakukan, adakah alternatif lain selain tindakan yang disarankan oleh dokter dan apa saja yang menjadi kemungkinan resiko yang dapat terjadi dan sekaligus berapa biaya yang mungkin akan ditanggung oleh pasien jika tindakan tersebut dilaksanakan. Jika semuanya telah dijelaskan dengan seksama maka pilihan ada pada pasien, apakah dirinya setuju atau tidak setuju tindakan tersebut dilakukan. Jika pasiennya setuju barulah diperbolehkan untuk membuat surat pernyataan persetujuan tindakan medis yang dimaksud. Jika pasien tidak setuju, maka tindakan yang disarankan oleh dokter tidak boleh dipaksakan untuk dilakukan, namun tidak berarti bahwa pasien tersebut harus ditelantarkan tetapi dokter dapat memilih beberapa tindakan alternatif yang jauh lebih menguntungkan bagi kesehatan dan keselamatan pasien.

Persetujuan tindakan medis yang diperoleh dokter sebelum melakukan tindakan medis pada pasien, terkadang tidak sesuai dengan syarat-syarat lahirnya sebuah persetujuan tindakan medis yang baik, dimana sebelum pasien membuat persetujuannya (consent), terlebih dahulu harus mendapatkan informasi yang jelas dan detail (informed) tentang segala sesuatu yang akan dilakukan terhadap dirinya sehubungan dengan penyakitnya. Kesulitan memberikan penjelasan yang detail dan hanya memberikan informasi medis yang secukupnya dan meminta pasien menandatangani persetujuan tindakan medis sudah sering dialami oleh pasien dan atau keluarganya.

3. Haskard KB, Williams SL, DiMatteo MR, Rosenthal R, White MK, Goldstein MG. Physician and patient communication training in primary care: effects on participation and satisfaction. Health Psychology. 2008, hlm. 27.

Vol. 20 No. 2 November 2018 
Pelaksanaan Tanggung jawab rumah sakit atas hak persetujuan tindakan medis bagi pasien merupakan sebuah syarat mutlak dalam pemberian pelayanan kesehatan kepada pasien. Pelaksanaan tindakan medis yang dilakukan oleh dokter atau pihak rumah sakit tanpa pemberitahuan dan persetujuan terlebih dahulu oleh pasien adalah sebuah perbuatan malpraktek medis, dimana dokter atau pihak rumah sakit dapat dipersalahkan karena perbuatannya baik karena kesengajaan ataupun karena kelalaiannya tidak meminta persetujuan tindakan medis pada pasien,apalagi jika akibat tindakan yang dilakukannya menimbulkan kerugian pada pasien.

Kewajiban dokter atau pihak rumah sakit untuk melaksanakan hak atas persetujuan tindakan medis bagi pasien dalam pelayanan kesehatan diatur dalam Pasal 37 ayat (1) Undang-Undang Nomor 44 Tahun 2009 Tentang Rumah Sakit yang berbunyi "Setiap tindakan kedokteran yang dilakukan di Rumah Sakit harus mendapat persetujuan pasien atau keluarganya “. Selanjutnya dalam Pasal 45 Undang-Undang Nomor 29 Tahun 2004 Tentang Praktek Kedokteran , mengatur tentang persetujuan tindakan medik yang berbunyi :

1) Setiap tindakan kedokteran atau kedokteran gigi yang akan dilakukan oleh dokter atau dokter gigi terhadap pasien harus mendapat persetujuan.

2) Persetujuan sebagaimana dimaksud pada ayat (1) diberikan setelah pasien mendapat penjelasan secara lengkap.

3) Penjelasan sebagaimana dimaksud pada ayat (2) sekurang-kurangnya mencakup :

a) diagnosis dan tata cara tindakan medis;

b) tujuan tindakan medis yang dilakukan;

c) alternatif tindakan lain dan risikonya;

d) risiko dan komplikasi yang mungkin terjadi; dan

e) prognosis terhadap tindakan yang dilakukan.

4) Persetujuan sebagaimana dimaksud pada ayat (2) dapat diberikan baik secara tertulis maupun lisan.

5) Setiap tindakan kedokteran atau kedokteran gigi yang mengandung risiko tinggi harus diberikan dengan persetujuan tertulis yang ditandatangani oleh yang berhak memberikan persetujuan.

Selanjutnya terhadap pelaksanaan tanggung jawab rumah sakit atas hak persetujuan tindakan medis bagi pasien berdasarkan tanggapan responden dokter dan pasien pada Rumah Sakit Labuang Baji, Bhayangkara, Pelamonia dan Lakipadada diperoleh gambaran data sebagai berikut : 


\section{Tabel 3}

Distribusi tanggapan Responden Dokter terhadap tanggung jawab rumah sakit atas pelaksanaan Hak persetujuan tindakan medis bagi pasien dalam pelayanan kesehatan bagi pasien

\begin{tabular}{|l|c|c|}
\hline \multicolumn{1}{|c|}{$\begin{array}{c}\text { Hak persetujuan tindakan medis dalam } \\
\text { pelayanan kesehatan bagi pasien }\end{array}$} & Jumlah & Persentase \\
\hline Terlaksana & 32 & 84,1 \\
Kadang terlaksana & 4 & 11,3 \\
Tidak terlaksana & 2 & 4,6 \\
\hline Jumlah & 40 & $100 \%$ \\
\hline
\end{tabular}

Sumber data: Data primer setelah diolah, Tahun 2016.

Berdasarkan tabel di atas, tampak bahwa sebagian besar responden dokter menyatakan bahwa para dokter telah memberikakan penjelasan yang akurat tentang tindakan medis yang akan dilakukannya dan dapat dimengerti oleh pasien $(84,1 \%)$, kadang-kadang saja memberikan penjelasan yang akurat dan yang dapat dimenegrti oleh pasien $(11,3 \%)$ dan sisanya menyatakan tidak memberikan penjelasan yang akurat dan yang dapat dimengerti oleh pasien $(4,6 \%)$.

Selanjutnya mengenai tanggung jawab rumah sakit dalam pelaksanaan Hak Atas Persetujuan Tindakan Medis bagi pasien di rumah sakit dapat dilihat pada tabel berikut ini:

Tabel 4

Distribusi tanggapan Responden Pasien terhadap tanggung jawab rumah sakit atas pelaksanaan Hak atas persetujuan

Tindakan Medis bagi pasien

\begin{tabular}{|l|c|c|}
\hline \multicolumn{1}{|c|}{$\begin{array}{c}\text { Hak persetujuan tindakan medis dalam } \\
\text { pelayanan kesehatan bagi pasien }\end{array}$} & Jumlah & Persentase \\
\hline Terlaksana & 14 & 11,3 \\
Kadang terlaksana & 5 & 4,5 \\
Tidak Tidak terlaksana & 101 & 84,2 \\
\hline Jumlah & 120 & $100 \%$ \\
\hline
\end{tabular}

Sumber data: Data primer setelah diolah, Tahun 2016.

Berdasarkan tabel di atas, proporsi responden pasien yang menyatakan bahwa para pasien tidak mendapatkan pelaksanaan Hak atas persetujuan tindakan medis yang baik ,jelas dan akurat sebesar $84,2 \%$, Terlaksana hak atas persetujuan tindakan 
medis dengan baik,jelas dan akurat sebesar 11,3\% dan sisanya kadang-kadang terlaksana Hak Atas Persetujuan Tindakan medis sebesra 4,5\%.

Pada hakikatnya Hak persetujuan tindakan medis (informed consent), adalah suatu proses komunikasi antara dokter dan pasien tentang kesepakatan sebuah tindakan medis yang akan dilakukan dokter terhadap pasien (ada kegiatan penjelasan rinci oleh dokter). Penandatanganan formulir Informed Consent secara tertulis hanya merupakan pengukuhan atas apa yang telah disepakati sebelumnya. Formulir ini juga merupakan suatu tanda bukti yang akan disimpan di dalam arsip rekam medis pasien. Dalam hal tindakan medik yang yang akan dilakukan tanpa resiko yang berarti cukup dibutuhkan kesepakatan lisan saja.

Persetujuan Tindakan medik (Informed Consent), adalah sebuah hubungan hukum perikatan atau perjanjian antara dokter atau pihak rumah sakit dengan pasien menyangkut upaya kesehatan untuk menyembuhkan dan memulihkan kesehatan. Perjanjian ini sangat dikenal dengan istilah perjanjian terapeutik. Ada beberapa kaidah yang harus diperhatikan dalam menyusun dan memberikan Informed Consent agar hukum perikatan ini tidak cacat hukum, yaitu diantaranya adalah: tidak bersifat memperdaya (Fraud); tidak berupaya menekan (Force) dan tidak menciptakan ketakutan (Fear).

Permasalahan dalam persetujuan tindakan medik adalah apakah persetujuan yang diberikan oleh pasien kepada dokter atau pihak rumah sakit untuk melakukan tindakan medis pada diri pasien sebelumnya telah mendapatkan penjelasan yang cukup tentang alasan yang kuat mengapa harus dilakukan tindakan tersebut (indikasi medis), resiko jika tindakan tersebut tidak dilakukan, kemungkinan resiko yang mungkin akan terjadi dilakukan, prognosis dari tindakan yang akan dilakukan, alternatif tindakan lainnya yang dapat dilakukan dengan segala resiko, keuntungan dan kerugian dari tindakan tersebut dan berapa kisaran besaran biaya yang akan dibebankan kepada pasien akibat pelaksanaan tindakan tersebut. Jika hal tersebut telah dilaksanakan oleh dokter atau pihak rumah sakit kepada pasien dan pasien menyatakan persetujuannya dengan menandatangani berkas formulir persetujuan tindakan (informed consent ) dapat dikatakan bahwa dokter atau pihak rumah sakit telah melaksanakan tanggung jawabnya atas pelaksanaan hak persetujuan tindakan medis kepada pasien.Fakta ini membuktikan para dokter, atau pihak rumah sakit belum sepenuhnya melaksanakan tanggung jawabnya dalam memberikan penjelasan dan informasi yang akurat dan mudah dimengerti oleh pasien, sebelum pasien memberikan persetujuan tindakan medik sebagai suatu syarat mutlak untuk dilakukannya sebuah tindakan medis kepada pasien.

Dalam kenyataannya banyak terjadi berkas persetujuan tindakan medik telah dibuat dan ditanda tangani oleh pasien, atau keluarganya meski belum mendapakan informasi yang jelas dan akurat tentang pelaksanaan tindakan medis yang akan diterimanya. Pasien hanya disodorkan berkas persetujuan tindakan medik untuk ditanda-tangani dengan penjelasan seadanya dan bahkan penjelasan yang diterima oleh pasienpun bukan berasal dari pihak dokter yang akan melakukan tindakan tersebut, melainkan melalui tenaga kesehatan lainnya seperti perawat atau bidan . 
Dalam hal ini terkesan bahwa dokter atau pihak rumah sakit hanya berlindung dibalik form persetujuan tindakan medik yang telah ditandangani oleh pasien jika terjadi sesuatu yang tidak dikehendaki atas tindakan medis yang dilakukannya.

\section{Tanggung jawab Rumah sakit atas Hak memilih dokter bagi pasien}

Pelaksanaan tanggung jawab rumah sakit untuk mewujudkan hak pasien dalam memilih dokter yang akan merawatnya tentunya merupakan sebuah kewajiban yang harus dipenuhi untuk meningkatkan kualitas pelayanan dan tingkat kepuasan pasien sebagai pengguna dan penerima jasa layanan rumah sakit. Para dokter atau pihak rumah sakit menyadari bahwa pelaksanaan tanggung jawab akan hak memilih dokter bagi pasien dalam pelayanan kesehatan merupakan sebuah kewajiban,meskipun demikian pelaksanaan hak ini tidak mutlak harus terpenuhi karena berbagai faktor yang menjadi kendala dalam pemenuhannya.

Beberapa faktor kendala yang sering menjadi penghalang dalam pemenuhan hak pasien untuk memilih dokter dalam pelayanan kesehatan adalah keterbatasan dokter dan dokter spesialis pada rumah sakit tersebut dan juga karena status pasien ketika masuk di sebuah rumah sakit, apakah sebagai pasien pengguna kartu asuransi ataukah sebagai pasien umum yang membayar sejumlah tarif yang ditetapkan oleh rumah sakit.

Sesungguhnya sangat sulit untuk mewujudkan hak memilih dokter yang akan merawat pasien di rumah sakit, karena sistem yang mengatur pola pemberian pelayanan kesehatan di rumah sakit terkesan adanya perbedaan yang cukup menyolok antara pasien yang datang berobat dengan status pasien umum dengan pasien yang datang dengan status asuransi BPJS. Apalagi dengan sistem pergantian shift tugas bagi dokter spesialis, yang meskipun berada di tempat jika bukan shift tugasnya memeriksa sulit untuk diakses oleh pasien pada hari itu. Karena selain tidak bertugas hari itu, biasanya mereka berpraktek di rumah sakit swasta yang meskipun masih jam dinas sebagai Aparatur Sipil Negara (ASN) yang bertugas dirumah sakit pemerintah.

Selanjutnya mengenai pemenuhan tanggung jawab rumah sakit atas hak memilih dokter bagi pasien dalam pelayanan kesehatan dapat dilihat pada tabel dibawah ini :

\section{Tabel 5}

\section{Distribusi tanggapan Responden dokter terhadap pemenuhan tanggung jawab rumah sakit atas Hak untuk Memilih Dokter bagi pasien}

\begin{tabular}{|l|c|c|}
\hline \multicolumn{1}{|c|}{ Hak memilih dokter bagi pasien } & Jumlah & Persentase \\
\hline Terlaksana & 2 & 4,2 \\
Kadang terlaksana & 5 & 12,2 \\
Tidak terlaksana & 33 & 83,6 \\
\hline Jumlah & 40 & $100 \%$ \\
\hline
\end{tabular}

Sumber data: Data primer setelah diolah, Tahun 2016 
Berdasarkan tabel di atas, proporsi tanggapan responden dokter yang menyatakan bahwa pelaksanaan hak memilih dokter tidak dapat dilaksanakan sepenuhnya oleh rumah sakit sebanyak 83,6 \%, kadang-kadang dapat terlaksana $12,2 \%$ dan yang menyatakan dapat terlaksana sebanyak 4,2\%.Sementara itu, tanggapan responden pasien dalam pelaksanaan hak memilih dokter dapat dilihat pada tabel berikut ini:

Tabel 6

Distribusi tanggapan Responden pasien terhadap pemenuhan tanggung jawab rumah sakit atas Hak untuk Memilih Dokter bagi pasien

\begin{tabular}{|l|c|c|}
\hline \multicolumn{1}{|c|}{ Hak memilih dokter bagi pasien } & Jumlah & Persentase \\
\hline Terlaksana & 4 & 3,3 \\
Kadang terlaksana & 6 & 5 \\
Tidak tidak terlaksana & 110 & 91,7 \\
\hline Jumlah & 120 & $100 \%$ \\
\hline
\end{tabular}

Sumber data: Data primer setelah diolah, Tahun 2016

Berdasarkan tabel di atas,tampak bahwa 91,7\% pasien menyatakan rumah sakit tidak dapat melaksanakan tanggung jawabnya untuk memenuhi hak pasien dalam memilih dokter dalam pelayanan kesehatan, kadang dapat melaksanakan tanggung jawabnya memenuhi hak pasien untuk memilih dokter $5 \%$ dan yang mengatakan dapat melaksanakan tanggung jawabnya memenuhi hak pasien memilih dokter dokter dalam pelayanan kesehatan 3,3\%.

Dari hasil penelitian ini, memperlihatkan bahwa pelaksanaan tanggung jawab rumah sakit untuk memilih dokter bagi pasien belum berjalan optimal. Meskipun para dokter menyadari bahwa pelaksanaan hak untuk memilih dokter tidak mutlak dilakukan pada semua pasien karena keterbatasan SDM dan karena faktor status pasien ketika masuk kerumah sakit sebagai pasien umum atau pasien asuransi (BPJS). Namun setidaknya, tidak ada perbedaan yang terlalu menyolok antara pasien umum yang membayar langsung seluruh biaya pemeriksaan kesehatannya dengan pasien asuransi yang terbatas pada pembayaran iuran asuransi mereka sesuai dengan kemampuan mereka masing-masing.

Dalam hal mendapatkan pelayanan kesehatan yang maksimal, tentunya pasien akan memilih dokter atau rumah sakit yang telah memahami riwayat penyakit yang dialaminya untuk mempercayakan kesehatan dan penyembuhan penyakitnya,meskipun pada dasarnya setiap dokter pada jenis spesialisasi yang sama memiliki kemampuan rata-rata yang hampir sama untuk memeriksa, mengobati, merawat dan bahkan melakukan tindakan medis tertentu yang berkenaan dengan spesialisasi atau keahliannya.

Mengenai Hak Memilih Dokter bagi pasien bukanlah hak yang bersifat mutlak, karena dapat dipengaruhi oleh berbagai faktor seperti ketersediaan tenaga dokter spesialis tertentu, faktor biaya atau jasa pelayanan yang mungkin akan di bebankan 
pada pasien, karena jika si pasien memilih dokter atau rumah sakit yang elite/asing maka otomatis biaya perawatan yang harus ditanggungnya lebih besar dibandingkan jika ia milih rumah sakit yang umum. 4 .

Meskipun dalam kenyataannya sangat sulit untuk mewujudkan hak untuk memilih dokter atau rumah sakit bagi pasien, namun setidaknya pelayanan yang diberikan kepada pasien harus memenuhi rasa keadilan bagi mereka semua. Pelayanan kesehatan yang diselenggarakan oleh rumah sakit haruslah berdasarkan prinsip yang aman, bermutu, anti diskrimintaif dan efektif, sebagaimana yang tertuang dalam Pasal 29 ayat (1) butir b UU No. 44 Tahun 2009 Tentang Rumah Sakit. Selanjutnya dalam Pasal 2 UU No. 29 Tahun 2004 disebutkan bahwa "Praktik kedokteran dilaksanakan berasaskan Pancasila dan didasarkan pada nilai ilmiah, manfaat, keadilan, kemanusiaan, keseimbangan, serta perlindungan dan keselamatan pasien“.

Penerapan prinsip keadilan dalam pelayanan kesehatan bagi para pengguna asuransi kesehatan seperti BPJS dalam memilih dokter yang akan merawat dirinya perlu mendapakan perhatian pemerintah sehubungan dengan pelayanan kesehatan yang bersifat antidiskriminatif yang tidak membedakan pelayanan yang diterimanya dengan pasien umum lainnya, sebagaimana yang diatur dalam Pasal $28 \mathrm{H}$ ayat (1) UUD NRI Tahun 1945 yang berbunyi : "Setiap orang berhak hidup sejahtera lahir dan batin, bertempat tinggal dan mendapalkan lingkungan hidup yang baik dan sehat serta berhak memperoleh pelayanan kesehatan". Hak atas pelayanan kesehatan adalah bagian dari hukum. Ini artinya setiap orang atau badan hukum atau bahkan Negara sekalipun harus menghormati dan berkewajiban memenuhi apa yang menjadi hak dari orang yang seharusnya mendapatkan pelayanan kesehatan tanpa harus membedakan antara si kaya dan si miskin dan pasien umum dan pasien asuransi BPJS.

\section{Tanggung jawab Rumah Sakit atas hak isi rekam medik bagi pasien}

Pelaksanaan tanggung jawab rumah sakit terhadap hak atas rekam medik pasien dalam pelayanan kesehatan, adalah sebuah kewajiban untuk menyimpan dan memelihara rekam medik yang berisi rahasia medis pasien yang hanya dapat dibuka atas seijin pasien yang bersangkutan atau atas kepentingan hukum di pengadilan. Berkas Rekam medik, adalah milik rumah sakit untuk disimpan dan diamankan kerahasiaannya, sedangkan isi rekam medis adalah milik pasien sehingga pasien berhak untuk mengetahui segala apa yang tercatat dalam berkas rekam medis tersebut.

Kerahasiaan isi rekam medis pasien yang menjadi tanggung jawab dokter atau pihak rumah sakit untuk menjaga dan melindunginya diatur dalam beberapa peraturan perundang-undangan, yaitu antara lain :

1) Pasal 48 UU No. 29 Tahun 2004 Tentang Praktek Kedokteran:

a) Setiap dokter atau dokter gigi dalam melaksanakan praktik kedokteran wajib menyimpan rahasia kedokteran.

4 Achadiat Chrisdiono. M, 1996 :6

Vol. 20 No. 2 November 2018 
b) Rahasia kedokteran dapat dibuka hanya untuk kepentingan kesehatan pasien, memenuhi permintaan aparatur penegak hukum dalam rangka penegakan hukum, permintaan pasien sendiri, atau berdasarkan ketentuan perundang- undangan.

2) Pasal 32 butir (i) Undang-Undang Nomor 44 Tahun 2009 Tentang Rumah Sakit yang berbunyi : "Setiap pasien berhak mendapatkan privasi dan kerahasiaan penyakit yang diderita termasuk data-data medisnya.

3) Pasal 57 ayat (1) UU No. 36 Tahun 2009 Tentang Tenaga Kesehatan yang berbunyi "Setiap orang berhak atas rahasia kondisi kesehatan pribadinya yang telah dikemukakan kepada penyelenggara pelayanan kesehatan”.

Pelanggaran terhadap ketentuantersebut, diancam pidana kurungan badan sebagaimana yang diatur dalam pasal 322 KUHP yang mengatakan "barang siapa yang dengan sengaja membuka rahasia yang wajib ia simpan karena jabatannya atau karena pekerjaannya, baik yang sekarang maupun yang dahulu, dihukum dengan hukuman penjara selama-lamanya sembilan bulan atau denda sebanyak-banyaknya sembilan ribu rupiah.

Sehubungan dengan kewajiban menyimpan rahasia medis, maka dokter atau pihak rumah sakit wajib membuat catatan-catatan rahasia medis yang baik untuk dijaga dan dilindungi kerahasiaannya sebagaimana yang diatur dalam Pasal 46 UU No. 29 Tahun 2009 sebagai berikut :

1) Setiap dokter atau dokter gigi dalam menjalankan praktik kedokteran wajib membuat rekam medis.

2) Rekam medis sebagaimana dimaksud pada ayat (1) harus segera dilengkapi setelah pasien selesai menerima pelayanan kesehatan.

3) Setiap catatan rekam medis harus dibubuhi nama, waktu, dan tanda tangan petugas yang memberikan pelayanan atau tindakan.

Dari hasil wawancara dengan informan dokter menyatakan bahwa masih terdapat sejumlah dokter kadang lalai atau telat menuliskan catatan-catatan medis hasil pemeriksaan yang telah dilakukan atau hanya sekedar menulis seadanya saja tentang apa-apa yang didapatkan didalam pemeriksaan tersebut. Sedangkan dari informan pasien diperoleh informasi bahwa pelaksanaan tanggung jawab rumah sakit atas Hak Isi Rekam Medis belum berjalan optimal, karena adanya kelalaian atau keterlambatan dari para dokter atau pihak rumah sakit dalam membuat dan mengisi berkas catatan medik pasien dengan baik, padahal idealnya segera setelah dokter memeriksa maka sebaiknya langsung mengisi catatan-catatan tersebut agar nantinya tidak lupa akan hasil dari pemeriksaan yang telah dilakukannya. Selain itu, masih terdapat kesulitan bagi pasien untuk mendapatkan keterangan atau informasi medis ,hasil pemeriksaan dokter yang telah di catat atau dibuatnya dalam berkas rekam medis tersebut karena keengganan petugas untuk memperlihatkan ataupun untuk menjelaskan kepada pasien hasil dari apa yang dicatatkan oleh dokter yang telah memeriksanya. 
Selanjutnya mengenai tanggung jawab rumah sakit terhadap pelaksanaan Hak Atas Rekam Medik bagi pasien dalam pelayanan kesehatan dapat dilihat pada tabel berikut ini.

Tabel 7

Distribusi Tanggapan Responden dokterterhadap pemenuhan Tanggung jawab rumah sakit atas hak Isi Rekam Medik bagi pasien

\begin{tabular}{|l|c|c|}
\hline \multicolumn{1}{|c|}{ Hak Isi Rekam Medik bagi pasien } & Jumlah & Persentase \\
\hline Terlaksana & 30 & 75 \\
Kadang terlaksana & 5 & 12,5 \\
Tidak terlaksana & 5 & 12,5 \\
\hline Jumlah & 40 & $100 \%$ \\
\hline
\end{tabular}

Sumber data: Data primer setelah diolah, Tahun 2016

Berdasarkan tabel di atas,tampak bahwa yang menyatakan bahwa pelaksaan hak atas rekam medik telah berjalan sesuai dengan ketentuan dan rahasia pasien tetap terlindungi sebanyak $75 \%$, yang hanya kadang-kadang berjalan optimal sebanyak 12,5 dan sisanya mengatakan tidak berjalan optimal sebanyak 12,5\%. Adapunpelaksanaan tanggung jawab Rumah sakit terhadap Hak Atas Isi Rekam Medik bagi pasien dalam pelayanan kesehatan dapat dilihat pada tabel berikut ini:

Tabel 8

Distribusi Tanggapan Responden Pasien Menurut Hak Atas Isi Rekam Medik

\begin{tabular}{|l|c|c|}
\hline \multicolumn{1}{|c|}{ Hak Isi Rekam Medik bagi pasien } & Jumlah & Persentase \\
\hline Terlaksana & 20 & 16.7 \\
Kadang terlaksana & 15 & 12,5 \\
Tidak terlaksana & 85 & 70,8 \\
\hline Jumlah & 120 & $100 \%$ \\
\hline
\end{tabular}

Sumber data: Data primer setelah diolah, Tahun 2016

Berdasarkan tabel di atas,tampak bahwa responden pasien yang menyatakan bahwa pelaksanaan Tanggung jawab dokter atau pihak rumah sakit terhadap hak atas isi rekam medis bagi pasien belum berjalan optimal sesuai dengan ketentuan sebanyak $70,8 \%$, yang menyatakan sudah berjalan sesuai dengan ketentuan sebanyak 16,7 \%, dan selebihnya yang kadang berjalan sesuai dengan ketentuan yang berlaku dan belum optimal sebanyak 12,5\%.

Menurut Buku Quo Vadis Kliniko Mediko Legal Indonesia dan Buku Penyelenggaraan Praktik Kedokteran Yang Baik di Indonesia Semua catatan tulisan 
dalam Rekam Medis harus dapat dibaca dan lengkap, harus otentik dan diberi tanggal dan waktu, langsung oleh orang yang bertanggung jawab untuk memberi instruksi, memberi atau mengevaluasi pelayanan yang diberikan (identifikasi dengan nama dan disiplin ilmu, tanda tangan, inisial tertulis atau pemasukan pakai komputer). Dalam hal dokter memberi instruksi via telepon untuk suatu tindakan medis, harus diterima oleh perawat senior, perawat tersebut harus membaca ulang perintah tersebut dan mencatatnya di rekam medik pasien. Dalam waktu paling lama 24 jam dokter yang memberi perintah harus menandatangani catatan perintah tersebut.Semua catatan data harus mendokumentasikan:

1) Bukti dari pemeriksaan fisik, termasuk riwayat kesehatan dan dilakukan tidak lebih lama dari 7 hari sebelum masuk rawat atau dalam jangka waktu 48 jam sesudah masuk rumah sakit.

2) Diagnosa masuk rawat.

3) Hasil dari evaluasi konsultasi pasien dan temuan yang cocok dengan staf klinik dan staf lainnya dalam merawat pasien.

4) Dokumentasi komplikasi, infeksi yang timbul di rumah sakit dan reaksi tidak cocok dengan obat dan anestesi.

5) Dijalankan dengan tepat formulir Informed Consent untuk prosedur dan tindakan yang ditentukan oleh staf medis, atau Hukum Federal atau Hukum Negara, apabila cocok, untuk memperoleh persetujuan.

Semua instruksi dokter, catatan perawat, laporan dari tindakan, data medikasi, radiologi dan hasil laboratorium, serta tanda tanda vital dan informasi lain yang diperlukan untuk memonitor keadaan pasien, harus di dokumentasikan dalam rekam medis, termasuk catatan pemulangan pasien dengan hasil masuk rawat, catatan kasus dan catatan pemberian perawatan follow up. Tidak lupa cantumkan diagnosis akhir/ringkasan pulang dengan melengkapi Rekam Medis dalam waktu 30 hari sesudah pemulangan.

Hasil penelitian membuktikan bahwa pelaksanaan Hak atas isi rekam medis masih perlu mendapatkan perhatian serius dari pihak rumah sakit, karena selain untuk kepentingan kesehatan juga dapat berimplikasi hukum dikemudian hari. Kepada pihak manapun kecuali atas persetujuan pasien atau karena perintah peraturan dan perundang-undangan yang berlaku. Karena berkas rekam medik berisi rahasia medik pasien maka pasien berhak untuk mengetahui apa isi rekam.

\section{PENUTUP}

Tanggung jawab rumah sakit terhadap pelaksanaan hak-hak pasien antara lain Hak Atas Informasi medis, Hak Atas Persetujuan Tindakan Medis, Hak Memilih dokter dan Hak Atas Isi Rekam Medis belum berjalan dengan baik sesuai dengan ketentuan dan peraturan perundang-undangan yang berlaku di bidang kesehatan. 


\section{DAFTAR PUSTAKA}

Anny lsfandyarie, 2006. Tanggung Jawab Hukum dan Sanksi Bagi Dokter, Prestasi Pustaka. Jakarta

2005. Malpraktek \&Resiko Medis dalam Kajian Hukum Pidana,Prestasi Pustaka, Jakarta.

Anny Isfandyarie. 2006.Tanggung Jawab Hukum dan Sanksi bagi Dokter. Prestasi Pustaka Jakarta.

Bahder Johan Nasution, 2005. Hukum Kesehatan Pertanggung jawaban Dokter. PT.Rineka Cipta.

Haskard KB, Williams SL, DiMatteo MR, Rosenthal R, White MK, Goldstein MG, 2008, Physician and patient communication training in primary care: effects on participation and satisfaction. Health Psychology.

Hendrojono Soewono, 2005 Batas pertanggung jawaban Hukum, Malpraktek dokter dalam transaksi terapeutik. Srikandi, Surabaya.

2006. Perlindungan Hak-hak Pasien Dalam Transaksi Terapeutik. Srikandi. Surabaya.

Hendrojono Soewono. 2006. Perlindungan Hak-hak Pasien dalam Transaksi Terapeutik. Srikandi Surabaya.

Isfandyarie. A. 2005.Malapraktik dan Resiko Medik dalam Kajian Hukum Pidana.Prestasi Pustaka. Jakarta

Munir Fuady, 2005. Sumpah Hippocrates: Aspek Hukum Mal Praktek Dokter. Citra Aditya Bakti, Bandung.

Ong LM, De Haes JC, Hoos AM, Lammes FB, 1995, Doctor-patient communication: a review of the literature. Social science \& medicine. 